\title{
Geopolitical Modernity and Pakistan Foreign Relations: How relevant?
}

\author{
Maria Bastos \\ University of Management and Technology, Lahore, Pakistan
}

\section{Introduction}

This article aims to explore the way modernity has been impacting Pakistan's foreign relations and policy, and whether it is relevant to use modernity as a political concept in order to understand them. The article is also an attempt to contextualize International Relations beyond the norms of Western Enlightenment by highlighting the real possibility for adoption of an interdisciplinary ground in order to approach fore ign relations. To be sure, most of International Relations theoretical basis used to study Pakistan foreign relations is situated within the realist paradigm. This fact comes with no surprise give the historicity of this young nation, and the context on which its foreign relations were built over the past sixty years, with particular attention to the Cold War scenarios, which left a significant mark in South Asia region in general and in Pakistan in particular.

Geopolitical considerations have been at the front of most Pakistan foreign relations and policy since its inception in 1947. The relation of geopolitical elements with modernity, concretely post-colonial modernity, on which Pakistan is immersed, I claim, needs to be redefined. Hence, and in order to ascertain Pakistan's relation with modernity in a geopolitical context, this article seeks to contribute to as a redefinition of the way Pakistan's foreign relations are thought, approached and studied.

A tension between tradition and modernity has been present in Pakistan's foreign relations. This tension is also evident on the building and consolidation of Pakistan as a nation-state. The building up of Pakistan as an independent country within the context of post-colonial modernity has been highly affected by events linked to the foreign relations the young nation procured to establish since 1947. Moreover, the domestic sphere of politics in Pakistan has been from the very beginning interdependent on external relations. This interdependency turns possible the drawing of a thin separation line between external and internal politics in Pakistan. 
Throughout the successive crises the country endured there is a factor that is often not taken into account when foreign relations and policy are approached. I'm referring to the concept of a geopolitical construction such as space. The 1971 war which resulted on the dismemberment of the country, with the creation of Bangladesh on its East wing, are, together with the Kashmir issue, the best examples on how geopolitical and space factors are relevant to engage with an alternative analysis of Pakistan foreign relations. To be sure, the country's history is highly consolidated on the narrative of Pakistan's foreign relations. What imports here is to study how geopolitical aspects of her post-colonial modernity have been influential on the historical developments that constitute the concept of Pakistan as a country.

Pakistan is a confessional nation-state. A country of majoritarian Muslim population, Pakistan enjoys a specific situation when it comes to tradition. The role of religion in Pakistan pervades all societal spheres.Islam plays, and has been playing, a decisive role on how the country relates with other nations, but also on how Pakistan relates with itself. It was because of the importance of Islam, not only as a religion but also due to its very political agency that Pakistan became into being. To some extent Pakistan can be seen as a representation of Islam. In fact, within the Muslim world, Pakistan enjoys an honourable place, a much revered country. The same unfortunately appears not to be the same within the Western world, and great part of the international community. The 'bad image' Pakistan carries is to a great extent due to the post 9/11 events and the realpolitik decisions taken at that time, aggravated by an alleged past support for terrorism, mainly related to the mujahedeen in Kashmir and the Taleban, during the Soviet invasion of Afghanistan, having that support continued past the Soviet leave. The possession of a nuclear arsenal, carrying the acronym of the 'Islamic Bomb', has also been contributing for Pakistan to be envisaged a dangerous, violent country, that the 'West' needs to deal with caution. These factscontributed for the denigration of Pakistan's image also often pictured as a nation immersed in backwardness. However, lest we forget that the high price of the so called 'war on terror' is in fact being paid at home. Here it appears the first challenge on what concerns approaching modernity and Pakistan's fore ign relations, a challenge that finds echoes on the current scenario of world politics.

Defining Modernity can be a daunting task, particularly since it is now unknown whether we live in modernity, or post-modernity. Notwithstanding, modernity has been defined as a departure from tradition, with clear positions against religion and its dogmatic foundations (Delanty, 2002:32). By this account, Pakistan would be automatically excluded from modernity, by simply being an Islamic Republic. However, discourses and representations of modernity go beyond the secularization 
tendency in society, and albeit always remaining a critique of tradition, the discourse of modernity also incorporates a multidimensional diversity, thus allowing us to think of Pakistan in context. Moreover it is not possible to conceive Pakistan's foreign relations apart from the forces of globalization, which are intrinsically part of modernity.

There is a tendency of the discourse of modernity to be universal, rationalist, routed on the European Enlightenment leaving little or no room to think on geopolitical terms in relation to its very own colonial legacy. This happened as the process of colonization by the Western Imperial powers in fact 'consolidated an idea of the West: a geopolitical image that exhibits chronological movement' (Mignolo, 2002:158). This geopolitical image of the West, resulted on an imaged turned to itself, and which asserted itself within past narratives. The future narratives that were developed within the colonial space, notwithstanding, kept the geopolitical identity of the local tied to an invisibility that, allied with other Eurocentrisms relegated the geopolitical other, to a second plan.

This oblivion of the geopolitical, of the spatial elements of the colonial experience, is the result of an Eurocentric discourse, invested of an almost blind rationality. However, and following Walter Mignolo assertion that ' coloniality is the hidden face of modernity' (2002:158), the spatial, geopolitical elements that undoubtedly are part of modernity, are perhaps also hidden, in the process that resulted from the universalization and rationality that were part and parcel with the logic of Enlightenment.

For the purpose of this article, the spatial dimension of modernity will be privileged, bearing in mind that universalistic propositions of modernity have relegated to a second plan the importance of location and geopolitics.

The very existence of Pakistan, a post-colonial state, born of the aspirations of creating an independent and separate nation-state to the Muslims of the Indian Subcontinent leaves us with important ground to think of Pakistan as a country with strong links to modernity, particularly to a specific moment when the hidden geopolitical elements, related to the colonial subject, started to ascend within it. Thus, the carving of Pakistan out of the Indian Subcontinent owes substantially to the conceptualization of space, embedded on concrete colonial experience of modernity. The geopolitical aspects of its creation, as well as its consequences till date, I sustain, can be better understood by situating Pakistan's foreign relations within the spatial dimension of modernity, which is intrinsically geopolitical.

To be sure, the concept of modernity is a much contested one, with multiple definitions, spanning across the social sciences. In that view, the present article 
does not aim to find a definitive answer to the proposed problem, since there are contingent and undecidable elements within the concept of modernity. However, the article aims to contribute for a better understanding of Pakistan's foreign relations and foreign policy.

The article will progress in three parts. First the focus will be on explaining how space and modernity can be thought together. Second part will focus on a concrete situation in terms of the relevance space had on the birth of Pakistan as a nationstate. Finally the article will conclude by asserting the ways modernity on its geopolitical, colonial dimensions have influenced Pakistan's foreign re lations, suggesting that an engagement with IR critical theories may benefit the scholarship.

\section{Modernity, Space and the making of Social Identities.}

It is widely accepted that modernity, if it is possible to put it on these terms, is a consequence of the European Renaissance and Enlightenment, within a more or less agreed period of time, starting during the seventeen century. This was a period where radical transformations took place in a wide range of areas. Arts, Literature, Science, all went under paradigmatic changes. Knowledge and enquiry too, found new ways to progress. The societal changes were just a consequence of the way authority and tradition were challenged, questioned and in many cases replaced by a new way of thinking, where reason was procured. Reason became invested of power, and that certainly brought up some of the most important consequences on modernity: a change on the political.

For instance, Antony Giddens's definition of modernity shows us the possibility to think on how of such changes became political ones. In Giddens words :' "modernity" refers to modes of social life or organisation which emerged in Europe from about the seventeenth century onwards and which subsequently became more or less worldwide in their influence.', (1990: 1). The 'new' modes of social life would change the organization of societies around the world, and particularly in Europe until today. With that change, the mode of political thinking also suffered alterations, with important impacts on geo-political approaches, since the colonial moment of modernity, until the contemporary post-colonial moment.

It is however important to register that the Enlightenment and for that matter modernity, has an extended link with colonialism. Such link, despite the dissipation of the colonial era, still is present on North-South re lations, one the preponderance of Western knowledge and power. Hence as Roxanne Doty timely reminds us: 
'Colonialism(s) represent $\mathrm{s}$ the collusion between power and knowledge and Enlightenment and humanist values at its extreme'. (1996: 24)

It is always the nexus power/know ledge conceived in Foucauldian terms that alerts us for the possibilities offered by studying the colonial side of modernity. However and for the purposes of the current study, is important to mention that 'usually accounts of modernity dismiss the significance of spatial relations in the emergence of the modern world.' (Maldonado-Torres 2004:39).

In order to understand the significance of modernity on Pakistan's foreign relations, it is necessary to clarify and indeed establish which modernity conceptualization can accommodate the particular history of Pakistan, its people and its current geo-strategic position. Thus, the concept of space on the terms I shall be low explain, may provide us with the possibility to ground an alternative waythink geopolitically about Pakistan. The relation between space and geopolitics will be then translated in a possible conception of modernity of which Pakistan is part. The concept of space willallow us to take such approach, and, in order to pursue, its relevance needs to be grasped.For that I believe that the work developed by Doreen Massey, one of the most influential contemporary geographers, within the radical tradition of politics may be useful. Belonging to a generation of geographers which emerged from the Marxist tradition, to whom, in general, space is a social construct, Massey has extensively written on issues of spatiality, temporality with a permanent engagement with the political dimensions of the same. For instance, Massey has long insisted that thinking spatially is never a neutral political activity (Featherstone \& Painter 2012:3). As pointed out by Featherstone \& Painter: '(she) mobilises a spatial perspective as a set of intellectual and political tools to bring clarity and purchase on diverse situations. It is because of the traction that such tools give to political questions that they have been central to her project. (...) she has profoundly reshaped common sense ways of thinking about space and place both in the discipline of geography and across the broader social sciences.' (2012:2).

Massey's considerations about space are of in-depth theoretical foundations, ranging from philosophical stances to more geography based ones. To the purpose of argument here presented it is more pertinent to focus of the political aspects of the concept of space, following Massey's theorizations.

\section{Why Space Matters?}

The development of Social Sciences in general and of IR theories in particular has been making room for an interdisciplinary collaboration. Hence, borrowing from a discipline such as geography may look at a first glance rather decontextualized. 
However, long ago Emmanuel Kant 'regarded the know ledge of geography (...) as a necessary precondition as well as the ultimate endpoint of all forms of human enquiry.' (Harvey 2009:133).

On the other hand, Pakistan's foreign relations as well as other countries foreig n relations do also represent a part of the Social. Foreign relations, I claim, are also social relations. As Massey notes: 'social relations always have a spatial form and a spatial content. They exist, necessarily, both in space (i.e. in a locational relation to other social phenomena) and across space. And it is the vast complexity of the interlocking and articulating nets of social relations which is social space.' (1994:168)

To think of fore ign relations as social relations is to presuppose that former are not disinvested of the needs and aspirations of the peoples ultimately represented by them. For this reason, thinking about space, spatial constructions, do matter in order to achieve an alternative understanding of foreign relations, in this case focusing on the geopolitical as being a constitutive part of space, albe it invested of a social component.

Hence, the geopolitical aspects that prevail on Pakistan's foreign relations since 1947 , can be understood within a context which also privileges 'the social' and not only the 'strategic'. By privileging 'the social', using the concept of space, it turns possible to grasp the importance that modernity, through its spatial elements, has been playing in Pakistan's foreign relations. That is particularly interesting to observe on how the Kashmir issue, which in fact was the first and still remains Pakistan's most important fore ign affair, has contributed for the formation of local and national identities, which happened due to the formation of subjectivities thus grounded on the relevance of space.

On this article I draw attention to the Kashmir issue and dispute as a condition for the possibility to observe a concrete and specific event where thinking about space extends itself into the 'sphere of multiplicity, the product of social relations, and those relations are really material practices, and always ongoing, space can never be closed, there will always be loose ends, always relations with the beyond, always potential elements of change.' (Massey 2005:95).

For instance, concerning the creation and development of the rather heterogenic Pakistan national identity, the Kashmir issue, I claim, has been playing a decisive role, a unifying role. If there is a point which does not cause divisions within Pakistanis is Kashmir. It is a point against which the national imaginaries has been created and solidified. 


\section{Space, the idea of Pakistan and Kashmir.}

Pakistan's foreign relations started primarily with India, soon after $14^{\text {th }}$ August 1947, shadowed by conflict. The Kashmir dispute, which prevails until today, became a serious contention, and ultimately escalated to war in 1948. As a result, Pakistan relations with India were from the beginning surrounded by mistrust, anger, bitterness and a profound sense of injustice felt by Pakistan.

The concept of space, I claim, has been directly at the centre of this relationship, which in fact started much earlier before the consummation of the Partition. For instance, the rise of the Muslim anti-colonial movement in British India, was already incorporating a spatial element on their struggle, as Asaf Hussain explains:

The Muslims were there- fore polarized into two factions: one visualized the need for a homeland to safeguard Islam (religion being more important than the individual); the other wanted a homeland for the Muslim minority (where the minority rights of the individual were more important than the religion). Both factions, however, perceived that the common danger they faced came from Hindu domination and not from the British Raj. (1976:921)

As we can see, the notion of a 'homeland', albeit to serve different purposes, was present at the heart of Indian Muslims struggles, who envisaged a spatial construct as part for the solution of their social issues. Consequently, the spatial questions on its geographical and social dimensions played an important role on the quest for Pakistan, and were intrinsically associated with the very idea of Pakistan. Such is possible to find in the in the famous inspirational words of Muhammad (Allama) Iqbal, Pakistan's made national poet. On his address to theAll-India Muslim League annual sessions in 1930 and 1932, the dimension of space and territoriality were acknowledged. Iqbal reflected upon the need of creating a separate homeland for the Indian Muslims. Albe it Iqbal's ideas about the existence of a nation-state and its consequences for the future of Islam, vis a viswhat happened to Christianity, may reveal that he was opposed to it, nevertheless he visualized the future of a Muslim Indian State as follows:

I would like to see the Punjab, North-West Frontier Province, Sind and Baluchistan amalgamated into a single state. Self-government within the British Empire our without the British Empire, the formation of a consolidated North-West Indian Mus lim State appears to be to be the final destiny of the Muslims. At least of North-West India. (Muhammad Iqbal, cited in Raja, 2010:128,129) 
Despite this clear vision from Iqbal, what followed next was much in the direction of confusion and dispute. It is interesting to note that on the almost prophetic words of Iqbal, there is no reference to Bengal, which was one of the provinces, together with Punjab that were sliced. Moreover, before the geographical location of what became Pakistan to be decided, the idea of Pakistan was not accompanied with a territorial contour, proved by the existence of three different maps, meaning that 'Pakistan was an imaginary, nationa list dream as well as a cold territorial reality.' (Khan 2007:44).

Thus, despite of the unclear geographical and cartographical contours on the options of those at the negotiations table, delineating the independence of India and the birth of Pakistan, it is possible to conceive the idea of Pakistan as a spatial one. Here it is possible to engage with space, which enables the possibility for multiplicity and relational to happen, as argued by Massey (2005:183). This multiplicity , allowing for a geographical representation as per Iqbal's vision, and for the integration of socio-political elements, such as the need for a society to be organized in order to fulfil the needs and aspirations of the British India Muslims. Whereas the former is limited to the objectivation of geopolitical aspects, the later goes beyond that and inscribes on itself the social and ideological components of Pakistan. Thus, the spatial idea of Pakistan, does offer us a base to ground not only the geographical and consequently the geopolitical disputes present on foreign relations with India, but also with other countries and world regions. Pakistan became more than a sovereign territory. Pakistan became space. What followed next was a conflictual negotiation of this space, which lasts until today, externally and internally.

The birth of Pakistan, with its territorial components gave origin from the very beginning to an intense and violent external exchange. In other words, Pakistan foreign relations were based on conflict from its inception. From this fact it is possible to draw two scenarios with relation to the spatial challenge of colonial modernity. The first scenario, the effective partition of British India, with territorial division based on identity constructions, was the one of the first steps toward the end of the colonial era. The role of space, intimal with the creation of Pakistan (East and West), was a political one, which dictated the way modernity would be extended into the post-colonial era. The second scenario saw Pakistan's foreign relations being immediately absorbed by the dispute with India over Kashmir. Hence, from its inception it is possible to claim that Pakistan's foreign relations were linked to conflictual spatial questions that would be translated into relational and constitutive elements of Pakistan's social and political identity. 


\section{Thinking spatially about Kashmir.}

Drawing back into the history chapter of the Partition, more precisely to the grounds upon which the same was agreed between the intervenient parties, it is perhaps the Kashmir issue that best illustrates the importance of the spatial dimension on Pakistan's foreign affairs, as per the considerations above mentioned. To be sure, there are numerous reasons to believe that the partition plan committed gross errors which turned unfavourably to Pakistan. The Kashmir issue is alarming, and I would venture to say that after Palestine, Kashmir heads the top on what concerns grave political mistakes and unjust decisions in the domain of world political affairs. There are of course many other cases, depending on individual and institutional evaluations. Such political mistakes committed at the end of colonial imperialism as we know it, would be the cause of wars, poverty and an extreme imbalance of power. The consequences however, are still felt almost seventy years later, and with no end on sight in a near future.

For a newly founded country, seeing the efforts of painful negotiations being blown in such a fashion was not acceptable, and just made the difficult birth more complicated. Not only the country became deprived of a vital part of its territory, with important losses from the geopolitical point of view, but also the populations which were excluded from Pakistan saw their lives going from one kind of colonialism to yet another.

The expansion of the post-colonial modernity, based on the spatial considerations here mentioned had its first blowback in the mountainous region of Kashmir. Until today, it is possible to say that the expansion of post-colonial modernity has been suspended in Kashmir, with clear disadvantage for Pakistan in general, and to the inhabitants of India occupied Kashmir in particular. The later continue to live under the most militarised area in the world and are victims of a brutal repressive force at the hands of the Indian State, which invades all forms of social organization, and grossly violate human rights of its own citizens, if we follow the idea that Kashmir is an integral part of India, as the Indian State narrative goes. Torture, massacres and more recently the discovery of mass graves (see, for instance,http://www.theguardian.com/world/2011/aug/21/kashmir-unmarkedgraves-thousands-bodies) are the legacy of 'largest democracy in the world'.

To be sure, the partition plan encountered several issues with the so called 'princely states', which, probably would not have happened should the India independence act of 15 June 1947, have been respected. Despite Lord Mountbatten's clarifications that 'the Indian states had been independent in treaty relations with the British, (...) and were absolutely free (my italics) to join one 
Constituent Assembly or the other, or make some other arrangement.' (Khan 2001:43), serious incidents and much on the way of conspiracy, mainly from elements linked to Nehru's entourage of bureaucrats did happen.

Nevertheless, most of the accession issues with the princely states were solved without much belligerence. Exception goes for Kalat in Baluchistan, which, unilaterally, declared independence on 11 August 1947 trigging a subsequent military intervention. However the Khan of Kalat reconsidered and choose to remain with Pakistan. Curiously after the Khan (of Kalat) had at the time of intervention completed the accession process, his younger brother mounted a rebellion, and the use of force could not be prevented in April 1948. (Ahmed 2013:67).

Another notorious case refers to the princely state of Hyderabad, which contrary to Kashmir, had a Muslim ruler and its population was majority Hindu. Hyderabad aspired to be an independent state. Geographically surrounded by what would be contemporary India, however ended up being occupied by India in 1948, after a military intervention (and curiously soon after Jinnah's dead). Amin (2000) refers to a historical version of events, according to which the Home Minister of India, Sardar Patel, had shown interest on exchanging Hyderabad for Kashmir. The offer was obviously and wisely rejected by Jinnah. In fact, Jinnah supported Hyderabad independence aspirations, in line with what was announced by Mountbatten (see above).

However, it was with the Princely state of Jammu and Kashmir that Pakistan and India relations became bitter and till date, signs of improvement of bilateral relations rarely focus on the very nature of the dispute. The history of Jammu and Kashmir has been linked to the Islamic Tradition for centuries. Power disputes were however frequent ever since, and even the Mughal Empire encountered serious difficulties to incorporate the region. This was the moment when Kashmir, as an independent territory became to an end, marking the beginning of Kashmir modern history (Schof ield 2000:3).

There are numerous reports of the uniqueness of Kashmir. It's outstanding beauty, the mountains, the valleys, the mystic traditions and the importance of spirituality that the whole region represents have long ago entered the collective mind of South Asian peoples, but also Western ones. For instance, Shuja Nawaz on his seminal book Cross Swords (2008), mentions that a certain English writer named John Keay speaks of explorers wanting to make of Kashmir ' a little England in the heart of Asia' and of their ideas of connecting South with Central Asia. (2008:35). 
Nawaz makes yet other interesting remark: 'If geography is destiny, Kashmir inherited an important role in the history of the subcontinent' (2008:35).

Others have been talking of Pakistan as being a prisoner of its geography (Talbot 2012:17). For that Kashmir accidentally has given some contribution. In fact Jinnah had long ago perceived the geopolitical importance of the country, vis a visthe menace of the Soviet influence throughout Asia (Ahmed 2013: 88). Hence the geopolitical factor seems to have been determinant, from Kashmir to other regions of the country, with special reference to the north-west frontier, boarding Afghanistan.

It is not the aim of this article to go in-depth on the intricacies and strategic considerations of the First Kashmir war. What is important to retain is the fact that Kashmir affair represents more than a conflict. Its geopolitical contours are not exclusively of physical nature. The geopolitical representations of the conflict became part and parcel with the tribulations Pakistan's peoples have faced ever since. The geographical and geopolitical elements involved on the Kashmir conflict, such as the control of water resources and access to the emblematic Silk Route, and the proximity with China and Central Asia are certainly crucial issues which should mark presence on every in-depth analysis of Pakistan's foreign relations and policy.

Notwithstanding, the socio-political implications of Kashmir envisaged as a space that is also socially constructed, are paramount for an alternative understanding of the geopolitical modernity in Pakistan's foreign relations. For instance, the role of the military in the country, its hegemonic power from within Pakistan's societal organization owns much to the primary events in Kashmir. By thinking spatially may contribute for such understanding, and perhaps unfold and facilitate the assimilation of alternative narratives.

The fact that Pakistan was forced to fight a war within less than one year of its existence, when it was totally overwhelmed with the refugee crisis and the lack of infrastructure, a war that was perceived as the result of betrayal, left open wounds till date. Moreover it opened up the possibility for the military heading most of Pakistan's foreign policy. The extension of its role is so vast that 'even during the periods of civil rule the army has wielded immense influence behind the scenes with respect to key aspects of foreign and security policy' (Talbot 2012:7). The military, for its immense power and influence on almost strategic and constitutive moments of the Pakistan, and for the role it plays on the social organization of Pakistan, is undoubtedly a key player, on the narrative between the country's foreign relations and modernity. 


\section{Conclusion}

The concept of Modernity is in itself controversial, and contingent. There is not a single definition of what it entails. The end of the European Empires, and particularly the end of the British colonial rule in India can be considered an important temporal mark, toward the end of one of many chapters of modernity: the colonial era. With it, the reconfiguration of world politics, with the appearance of new nation-states, as Pakistan, gave a new impulse for the politicization of identities. With Pakistan, and throughout the colonised Islamic world, a new movement for liberation started to gain momentum, ultimately resulting on the independence of many new nations in Asia and Africa.

Identities and their construction are relational. The formation of a possible Pakistan national identity, which, I concede, is yet in a formation process, with no agreement on what it may actually be or become, on its less controversial elements, owns a great amount to the established foreign relations, in particular with India, against which the base of national identification has been built.

On the particular case of Pakistan, foreign re lations have been majorly contentious processes, especially with its immediate neighbours, India and Afghanistan. On what concerns Pakistan's foreign relations there is a socio-spatial dimension which has been present from the very beginning, and which, I claim, has been misrepresented on mainstream analys is of Pakistan's foreign affairs. The result of such misrepresentation has been the withdrawal of Pakistan from a certain kind of modernity, a geopolitical modernity, which, in turn, is related with the fact that colonial modernity (to and from which Pakistan exists and emerged) has often denied the possibility for thinking spatially.

The example of Kashmir shown on this article, may allow to bring the problematic to the fore. The current study aimed to demonstrate the importance and the possibilities that thinking in terms of space, may bring to the analysis of foreign relations.

Concomitantly, this study also attempted to highlight the usefulness of critical approaches to International Relations, particularly those who privilege the space of the post-colonial subject, be it a young nation-state such as Pakistan, or her people. To be sure, the livings of the peoples outside IR mainstream theories can better be apprehended if, at times, the analysis of world politics will abandon privileged modes of analysis, and try to think differently. This study hopes to contribute for the encouragement of such practice and at the same time contextualize the concept of modernity for Pakistan foreign relations. 


\section{References and notes:}

Ahmed, I. (2013). Pakistan the Garrison State: Origins, Evolution, Consequences 1947 2011. Oxford University Press.

Amin, S. M. (2000). Pakistan's foreign policy: a reappraisal. Oxford: Oxford University Press.

Ashley, R. K. (1987). The geopolitics of geopolitical space: toward a critical social theory of international politics. Alternatives: Global, Local, Political,12(4), 403-434.

Delanty, G. (2000). Modernity and postmodernity: Knowledge, power and the self. Sage.

Doty, R. (1996). Imperial Encounters (Minneapolis, MN. University of Minnesota Press

Featherstone, D., \& Painter, J. (Eds.). (2012). Spatial Politics: Essays for Doreen Massey. John Wiley \& Sons.

Giddens, A. (1990). The Consequences of Modernity Cambridge. Polity

Harvey, D. (2009). Cosmopolitanism and the Geographies of Freedom. Columbia University Press.

Hussain, A. (1976) Ethnicity, National Identity and Praetorianism: The Case of PakistanAsian Survey, Vol. 16, No. 10 (Oct., 1976), pp. 918-930

Khan, H. (2001). Constitutional and political history of Pakistan .Karachi: Oxford University Press.

Khan, Y. (2007). The great partition: The making of India and Pakistan. Yale University Press.

Maldonado-Torres, N. (2004). The topology of being and the geopolitics of knowledge: Modernity, emp ire, coloniality 1. City, 8(1), 29-56.

Massey, D. (1992). Politics and space/time. New Left Review, 65-65.

Massey, D. (1994). Space, place and gender. Polity Press

Massey, D. (2005). For space. Sage.

Massey,D. (2004). Geographies of responsibility. GeografiskaAnnaler: Series B, Human Geography, 86(1), 5-18.

Mignolo, W. (2002) "The many faces of Cosmo-polis: Border Thinking and Critical Cosmopolitanism" in Breckenridge, C. A., Pollock, S., \&Homi, K. Bhabha, and DipeshChakrabarty, eds. 2002.Cosmopolitanism

Nawaz, S. (2008). Crossed swords: Pakistan, its army, and the wars within. Oxford University Press, Karachi.

Raja, M. A. (2010). Constructing Pakistan: Foundational Texts and the Rise of Muslim National Identity. Oxford: Oxford University Press.

Schofield, V. (2000). Kashmir in conflict: India, Pakistan and the unending war. IB Tauris. Talbot, I. (2012). Pakistan: a new history. Oxford: Oxford University Press. 


\section{Summary}

\section{Modemity and Pakistan Foreign Relations: How relevant?}

\section{Maria Bastos}

\section{University of Management and Technology, Lahore, Pakistan}

The article discusses the importance of geopolitical and spatial dimensions, as part of modernity, on Pakistan's foreign relations. Drawing on the context of modernity, the article argues that in order to think Pakistan foreign relations in alternative to mainstream IR theories, the concept of space, with its social dimensions is a useful concept. Since Pakistan's inception in 1947, foreign relations, particularly with India, have been marked by tensions, which on its turn are grounded on space issues. By resourcing to historical events, the article shows the importance of space in Pakistan's formation, and how foreign relations have also been consequently shaped. The article concludes that the concept of space plays an important role when analysing foreign relations, also opening the possibility for the analysis of Pakistan foreign relations away from mainstream IR theories.

Ke ywords: space, modernity, Pakistan, Kashmir, foreign relations, India, geopolitical. 